\title{
Evaluation of Hydrocarbons Level and Identification of Indigenous Bacteria in Soil from Auto-Mechanic Workshops along Ikokwu Mechanic Village, Port Harcourt, Nigeria
}

\author{
*1AKOMAH, ON; ${ }^{2}$ OSAYANDE, AD
}

\begin{abstract}
${ }^{I}$ Microbiology Technology option, ${ }^{2}$ Geology and Mining Technology option School of Science laboratory Technology, University of Port Harcourt, PMB 5323 Choba Port Harcourt Nigeria. *Email: onyinyechi.akomah@yahoo.com; onyinyechi.akomah@uniport.edu.ng
\end{abstract}

\begin{abstract}
Soil samples collected from Ikokwu auto-mechanic village Mile 3, Port Harcourt, Nigeria were analyzed for the microbiological and hydrocarbon content using standard culture dependent and physiochemical methods. Five sets of soil designated A, B, C, D and E were collected using composite technique at depth $0-15 \mathrm{~cm}$ and $15-30 \mathrm{~cm}$. The parameters analyzed over an experimental period of 60 days were; total heterotrophic bacteria (THB), hydrocarbon utilizing bacteria (HUB), total petroleum hydrocarbon (TPH), polyaromatic hydrocarbon $(\mathrm{PAH})$ and total hydrocarbon content (THC). The total heterotrophic bacterial count (THB) ranges from $1.36 \times 10^{6}-1.10 \times 10^{8} \mathrm{cfu} / \mathrm{g}$ for A- E (0-15) cm and $5.0 \times 10^{5}-7.0 \times 10^{7} \mathrm{cfu} / \mathrm{g}$ for (15-30) $\mathrm{cm}$ while the total hydrocarbon utilizing bacteria (HUB) count ranges from $3.5 \times$ $10^{5}-5.4 \times 10^{6} \mathrm{cfu} / \mathrm{g}$ for $(0-15) \mathrm{cm}$ and $2.0 \times 10^{5}-9.4 \times 10^{6}$ for $(15-30) \mathrm{cm}$. The bacteria isolates included the genera Bacillus sp., Flavobacterius sp., Pseudomonas sp., Micrococcus sp., Arthrobacter sp., Acetobacter sp., Proteus sp. and Staphylcoccus sp. The TPH ranges from $34.32-1746.6 \mathrm{mg} / \mathrm{kg}$ for $(0-15) \mathrm{cm}$ and $29.49-1141.0 \mathrm{mg} / \mathrm{kg}$ for $(15-30) \mathrm{cm}$. The THC ranges from $1.3-5.66 \mathrm{mg} / \mathrm{kg}$ for $(0-15) \mathrm{cm}$ and $0.84-2.719 \mathrm{mg} / \mathrm{kg}$ for $(15-30) \mathrm{cm}$. PAH recorded a value of $3.246-$ $6.890 \mathrm{mg} / \mathrm{kg}$ for $(0-15) \mathrm{cm}$ and $0.096-2.860 \mathrm{mg} / \mathrm{kg}$ for $(15-30) \mathrm{cm}$. It is recommended that (i) the hydrocarbon degraders be enhance and employed for bioremediation of auto-mechanic workshop (ii) it is essential that the metagenomics of spent engine oil contaminated soil at auto-mechanic workshop be studied for optimum utilization of their potentials.

DOI: https://dx.doi.org/10.4314/jasem.v22i1.21
\end{abstract}

Copyright: Copyright (C) 2017 Akomah and Osayande. This is an open access article distributed under the Creative Commons Attribution License (CCL), which permits unrestricted use, distribution, and reproduction in any medium, provided the original work is properly cited

Dates: Received 18November 2017; received in revised form 3December 2017; accepted 21 January 2018

Keywords: Soils, Polyaromatic Hydrocarbons, Spent engine oil, hydrocarbon utilizing bacteria

Auto-mechanic workshop also called garage or automobile repair shop is a portion of land where repair and services of vehicles is done. In most developing countries. Nigeria not an exception, the practice is the importation of vehicles which in turn necessitate the establishment of more auto-mechanic workshop (Nwoko et al., 2007). Ikokwu auto-mechanic village is a bee hive of activities. Services such as serving of vehicle engines, repair of fuel tanks, repair or charging of batteries, repair of brake systems, repair of clutch system and overhauling of vehicle engines are been carried out. Its environment has a characteristic black color, littered with pieces of metal scrape from cars and contaminated with spent engine oil. The surface hard and devoid of plant. These services provided by the workshop generate huge waste such as spent engine oil (motor oil), grease, hydraulics, petrol, electrolyte, clutch fluid, sludge and paint (Nwachukwu et al., 2010). Engine oil is use as lubricant for part of automobile engine in order to keep them running smoothly (Hagwell et al., 1992). It contain high content of polyaromatic hydrocarbon (PAHs) (naphthalene, anthracene, phenols, benz(a)anthrancene, benzo(a)pyrene, fluranthene (Jain et al., 2009). PAHs have attracted much attention because some of them are strong carcinogens i.e benzo(a)pyrene and benzo(a) anthracene (IARC, 2007) and their introduction into the environment could be detrimental. The environment is all the external factors affecting an organism. These factors may be other living organisms (biotic factors) or nonliving variables (abiotic factors). The existence of the biotic components is a function of the relationship between the abiotic and biotic compartment of a given environment. Even minute changes in any one factor in an environment can influence whether an organism will be successful in its environment (Michael 2009). The unsystematic discharging of auto-mechanic workshop waste (spent engine oil) as resulted in the degradation of the environment owning to the fact that change or disturbance to the environment perceived to be deleterious or undesirable is refer to as environmental degradation (Johnson et al., 1997). Daily discharge of spent engine oil could affect the microbial population in oil polluted environment. Studies have shown that more hydrocarbon utilizing bacteria are isolated from soil with functional mechanic workshop than soil away from the workshop or non-functional mechanic workshop. The percentage of hydrocarbon utilizing bacteria presence at auto-mechanic workshop are higher than heterotrophic bacteria (Onwurah et al., 2007) therefore, the exploitation of some of these hydrocarbon utilizers for the remediation of engine oil contaminated sites. The study was aimed at evaluating the levels of hydrocarbon and 
identifying indigenous microbial population in soil samples from auto-mechanic workshops along Ikokwu mechanic village in Port Harcourt, Nigeria.

\section{MATERIALS AND METHODS}

The study site was Ikokwu mechanic village, Mile 3 Diobu, Port Harcourt, Rivers state, Nigeria. It is located between latitudes $4^{0} 47^{\prime} 56.8^{\prime \prime} \mathrm{N}$ and $4^{0} 68^{\prime} 06.7^{\prime \prime} \mathrm{N}$ and longitudes $6^{0} 59^{\prime} 36.4^{\prime \prime} \mathrm{E}$ and $6^{0} 59^{\prime} 37.8^{\prime \prime} \mathrm{E}$ within the Niger Delta sedimentary basin of Southern Nigeria.

Enumeration of total Heterotrophic Bacteria (THB): Total Heterotrophic Bacteria (THB) count was determined by pour plate method using nutrient agar. About $1 \mathrm{~g}$ of the samples were suspended in $9 \mathrm{ml}$ of sterile physiological saline. Subsequent 10 fold dilutions were made from this initial dilution up to $10^{-5}$. About 0.1 $\mathrm{ml}$ aliquots from $10^{-3}-10^{-5}$ dilution were inoculated into prepared nutrient agar plates in triplicate. The inoculated plates were incubated at $28^{\circ} \mathrm{C}$ for 24 hours after which plate counts were taken. Only culture plates that gave 30 - 300 colonies were counted and expressed in cfu/g and sub-cultured into freshly prepared nutrient agar for further identification.

Enumeration of Hydrocarbon Utilizing Bacteria (HUB): Mineral salt medium (MSA) was used for the enumeration and isolation of hydrocarbon utilizing bacteria. The method of Okpokwasili and Okorie, (1988) was adapted. The components of the medium in $\mathrm{g} / \mathrm{l}$ is $\left(\mathrm{NaCl} 10 \mathrm{~g}, \mathrm{MgSO} 0.4 \mathrm{~g}, \mathrm{KCl} 0.29 \mathrm{~g}, \mathrm{NaHPO}_{4} 1.25 \mathrm{~g}\right.$, $\mathrm{KH}_{2} \mathrm{PO}_{4} 0.83 \mathrm{~g}, \mathrm{NaNO}_{3} 0.42 \mathrm{~g}$ Agar $10 \mathrm{~g}$ ). About $1 \mathrm{~g}$ of the samples were suspended in $9 \mathrm{ml}$ of sterile physiological saline. Subsequent 10 fold dilution were made from this initial dilution up to $10^{-5}$. About $0.1 \mathrm{ml}$ aliquots of $10^{-3}-10^{-5}$ dilution were inoculated into molten MSA plates in triplicate. Vapour phase transfer was used to introduce the crude oil. The plates were incubated at $280 \mathrm{C}$ for 5 days. Only culture plates that gave 30 - 300 colonies were counted and expressed in cfu/g and sub-cultured into freshly prepared nutrient agar plates for further identification.

Identification of Isolates: The morphological characteristics of the isolates were identified by Gram stain and biochemical reaction according to the method of Cheesborough, (2000) as well as motility. The biochemical reaction include sugar fermentation test, catalase test, oxidase test, indole test, MR/VP test, $\mathrm{H}_{2} \mathrm{~S}$ test and spore staining.

Determination of Total Petroleum Hydrocarbon and Polyaromantic Hydrocarbon: The modified EPA 8015 technique was adapted (USEPA 2002b). Each soil sample were extracted with methylene chloride and aliquot $(1 \mu \mathrm{l})$ of the extract was injected into a gas chromatograph equipped with a flame ionization detector (FID) GC model Agilent Gas Chromatograph FID 689 ON.
Total Hydrocarbon Content: The soil sample were air dried and sieved through a $1 \mu \mathrm{m}$ sieve. $5 \mathrm{~g}$ of the sample was weighed into a conical flask, $10 \mathrm{ml}$ of n-hexane was added and the sample was extracted in a mechanic shaker. Additional $10 \mathrm{ml}$ of $\mathrm{n}$-hexane was used for complete extraction and the extract collected in a $25 \mathrm{ml}$ standard flask. This was finally made up to mark with nhexane. A sample cuvette was first filled with n-hexane as the blank solution and it was place in the sample holder of the spectrophotometer model Genesis $10 \mathrm{UV}$. The wavelength was set at $425 \mathrm{~nm}$ and the transmittance adjusted to $100 \%$ zero absorbance. The absorbance of the extracted oil was taken. The total hydrocarbon content was calculated from the gradient of the calibration curve.

$$
T H C, m g / k g=\frac{\text { Absorbance } x \text { Volume } x \text { Gradient } x 1000}{\text { Weight of sample used }}
$$

\section{RESULTS AND DISCUSSION}

Microbial Count: The total heterotrophic bacteria (THB) count of soil samples at depth $0-15 \mathrm{~cm}$ ranged from 1.36 x $10^{6}-1.10 \times 10^{8} \mathrm{cfu} / \mathrm{g}$ while depth $15-30 \mathrm{~cm}$ ranged from $5.0 \times 10^{5}-7.0 \times 10^{7} \mathrm{cfu} / \mathrm{g}$. The hydrocarbon utilizing bacteria (HUB) count of soil sample at depth $0-15 \mathrm{~cm}$ ranged from $3.5 \times 10^{5}-5.4 \times 10^{6} \mathrm{cfu} / \mathrm{g}$ while depth $15-30$ $\mathrm{cm}$ ranged from $2.0 \times 10^{5}-9.4 \times 10^{6} \mathrm{cfu} / \mathrm{g}$. The population of the THB and HUB at depth $0-15 \mathrm{~cm}$ are found to be higher than those at depth $15-30 \mathrm{~cm}$, as indicated in tables 1 and 2 .

Hydrocarbon Content of Soil: The total hydrocarbon content of soil sample at depth $0-15 \mathrm{~cm}$ ranges from 1.3 - 5.66 ppm while depth 15 - $30 \mathrm{~cm}$ ranged from 0.54 $2.719 \mathrm{ppm}$. The total petroleum hydrocarbon at depth 0 $15 \mathrm{~cm}$ for the various sampling points ranges from 34.32 - 1746.6 ppm while depth 15 - $30 \mathrm{~cm}$ ranges from 29.49 $1141 \mathrm{ppm}$. The polyaromatic hydrocarbon at depth $0-15$ cm ranged $3.246-6.89$ ppm while depth $15-30 \mathrm{~cm}$ ranges from $0.096-2.86 \mathrm{ppm}$ as shown in table 3 . The content of THC, TPH, and PAH at depth $0-15 \mathrm{~cm}$ is higher than at depth $15-30 \mathrm{~cm}$. Auto-mechanic workshops are noted for huge blanket discharge of spent and unspent engine oil and other refined petroleum products as a result of the activities undertaken in the workshop; serving, maintenance and repairs of vehicles (Fery, 2007). Soil samples collected from different spots at depth $(0-15) \mathrm{cm}$ and $(15-30) \mathrm{cm}$ are characterized by intense oil spillage, blackish and devoid of plant growth. Total heterotrophic bacteria count (THB), total hydrocarbon utilizing bacteria count (HUB), gas chromatograph-FID analysis were carried out on soil sample obtained from Ikokwu mechanic workshop PortHarcourt within a 60 day period. 
Table 1: Total Heterotrophic Bacterial count

\begin{tabular}{lllll}
\hline Samples & Day 0 (cfu/g) & Day 14 (cfu/g) & Day 28 (cfu/g) & Day 42 (cfu/g) \\
\hline A 0 - $15 \mathrm{~cm}$ & $1.95 \times 10^{7}$ & $1.10 \times 10^{8}$ & $4.2 \times 10^{7}$ & $1.36 \times 10^{7}$ \\
A $15-30 \mathrm{~cm}$ & $3.3 \times 10^{6}$ & $1.50 \times 10^{7}$ & $5.8 \times 10^{6}$ & $6.0 \times 10^{6}$ \\
B 0 - $15 \mathrm{~cm}$ & $9.3 \times 10^{6}$ & $1.80 \times 10^{7}$ & $1.05 \times 10^{7}$ & $1.09 \times 10^{7}$ \\
B $15-30 \mathrm{~cm}$ & $5.9 \times 10^{6}$ & $1.45 \times 10^{7}$ & $9.4 \times 10^{6}$ & $7.0 \times 10^{7}$ \\
C $0-15 \mathrm{~cm}$ & $8.510^{7}$ & $1.45 \times 10^{7}$ & $4.2 \times 10^{7}$ & $6.6 \times 10^{7}$ \\
C15 $-30 \mathrm{~cm}$ & $9.1 \times 10^{6}$ & $1.43 \times 10^{6}$ & $5.7 \times 10^{6}$ & $6.1 \times 10^{6}$ \\
D $0-15 \mathrm{~cm}$ & $1.28 \times 10^{7}$ & $2.35 \times 10^{7}$ & $7.1 \times 10^{6}$ & $9.3 \times 10^{7}$ \\
D15 $-30 \mathrm{~cm}$ & $8.0 \times 10^{6}$ & $5.4 \times 10^{6}$ & $6.6 \times 10^{6}$ & $4.0 \times 10^{7}$ \\
E 0 - $15 \mathrm{~cm}$ & $1.25 \times 10^{7}$ & $4.8 \times 10^{7}$ & $6.4 \times 10^{6}$ & $1.04 \times 10^{7}$ \\
E15 $-30 \mathrm{~cm}$ & $9.6 \times 10^{6}$ & $4.5 \times 10^{6}$ & $1.15 \times 10^{6}$ & $5.0 \times 10^{6}$ \\
\hline
\end{tabular}

Table 2: Total Hydrocarbon Utilizing Bacterial count

\begin{tabular}{|c|c|c|c|c|c|}
\hline Samples & Day 0 (cfu/g) & \multicolumn{2}{|c|}{ Day $14(\mathrm{cfu} / \mathrm{g})$} & Day 28 (cfu/g) & Day $42(\mathrm{cfu} / \mathrm{g})$ \\
\hline A $0-15 \mathrm{~cm}$ & $6.8 \times 10^{5}$ & \multicolumn{2}{|l|}{$9.8 \times 10^{5}$} & $5.8 \times 10^{5}$ & $5.9 \times 10^{5}$ \\
\hline A $15-30 \mathrm{~cm}$ & $7.0 \times 10^{5}$ & \multicolumn{2}{|l|}{$5.9 \times 10^{6}$} & $5.5 \times 10^{5}$ & $9.6 \times 10^{5}$ \\
\hline B $0-15 \mathrm{~cm}$ & $1.04 \times 10^{6}$ & \multicolumn{2}{|l|}{$8.0 \times 10^{5}$} & $1.25 \times 10^{6}$ & $1.13 \times 10^{6}$ \\
\hline B $15-30 \mathrm{~cm}$ & $1.02 \times 10^{6}$ & \multicolumn{2}{|l|}{$9.4 \times 10^{6}$} & $8.0 \times 10^{5}$ & $1.00 \times 10^{6}$ \\
\hline $\mathrm{C} 0-15 \mathrm{~cm}$ & $6.4 \times 10^{5}$ & \multicolumn{2}{|l|}{$5.4 \times 10^{6}$} & $8.5 \times 10^{5}$ & $5.5 \times 10^{5}$ \\
\hline $\mathrm{C} 15-30 \mathrm{~cm}$ & $1.03 \times 10^{6}$ & \multicolumn{2}{|l|}{$6.4 \times 10^{6}$} & $1.30 \times 10^{6}$ & $7.2 \times 10^{5}$ \\
\hline D $0-15 \mathrm{~cm}$ & $1.18 \times 10^{6}$ & \multicolumn{2}{|l|}{$7.0 \times 10^{5}$} & $5.0 \times 10^{5}$ & $1.15 \times 10^{5}$ \\
\hline D15 $-30 \mathrm{~cm}$ & $1.05 \times 10^{6}$ & \multicolumn{2}{|l|}{$6.5 \times 10^{5}$} & $1.18 \times 10^{6}$ & $9.8 \times 10^{5}$ \\
\hline E $0-15 \mathrm{~cm}$ & $1.04 \times 10^{6}$ & \multicolumn{2}{|l|}{$4.5 \times 10^{6}$} & $3.5 \times 10^{5}$ & $6.6 \times 10^{5}$ \\
\hline E15 $-30 \mathrm{~cm}$ & $8.0 \times 10^{5}$ & \multicolumn{2}{|l|}{$9.2 \times 10^{6}$} & $4.0 \times 10^{5}$ & $8.3 \times 10^{5}$ \\
\hline \multicolumn{6}{|c|}{ Table 3: Frequency of occurrence of Bacterial isolates } \\
\hline $\mathrm{S} / \mathrm{N}$ & \multicolumn{3}{|l|}{ Bacteria Isolates } & \multicolumn{2}{|l|}{ Percentage (\%) } \\
\hline 1 & \multicolumn{3}{|l|}{ Bacillus sp. } & \multicolumn{2}{|l|}{38.1} \\
\hline 2 & \multicolumn{3}{|c|}{ Flavobacterium sp. } & 11.9 & \\
\hline 3 & Pseudomonas sp. & & & 30.9 & \\
\hline 4 & Micrococcus sp. & & & 7.1 & \\
\hline 5 & Arthrobacteria s! & & & 4.8 & \\
\hline 6 & Acetobacter sp. & & & 2.4 & \\
\hline 7 & Proteus sp. & & & 2.4 & \\
\hline 8 & Stapholoccus sp. & & & 2.4 & \\
\hline Table 4: Hy & rocarbon Conte & ent of Soil & & & \\
\hline Parameters & $\mathrm{A}(\mathrm{ppm})$ & $\mathrm{B}(\mathrm{ppm})$ & $\mathrm{C}(\mathrm{ppm}$ & $\mathrm{D}(\mathrm{ppm})$ & $\mathrm{E}(\mathrm{ppm})$ \\
\hline THC & & & & & \\
\hline $0-15 \mathrm{~cm}$ & 1.3 & 5.66 & 4.534 & 2.891 & 3.772 \\
\hline $15-30 \mathrm{~cm}$ & 0.84 & 2.10 & 2.719 & 2.614 & 2.219 \\
\hline TPH & & & & & \\
\hline $0-15 \mathrm{~cm}$ & 1746.6 & 41.73 & 191.79 & 1169.6 & 34.32 \\
\hline $15-30 \mathrm{~cm}$ & 311.1 & 37.84 & 178.3 & 1141.0 & 29.49 \\
\hline PAH & & & & & \\
\hline $0-15 \mathrm{~cm}$ & 4.24 & 3.25 & 6.890 & 3.54 & 3.246 \\
\hline $15-30 \mathrm{~cm}$ & 2.86 & 2.19 & 0.096 & 1.91 & 2.193 \\
\hline
\end{tabular}

The total hydrocarbon content of the sample ranged from 0.84 - $5.66 \mathrm{ppm}$. The top soil contains higher concentration of THC than the bottom soil. The higher concentration resulted from the indiscriminate disposal of waste petroleum product (used engine oil, petrol, diesel and other lubricants) directly on the floor. The level of the total petroleum hydrocarbon vary across the sampling point, sample point A $(0-15) \mathrm{cm}$ having the highest value $(1746.6 \mathrm{ppm})$. Sample depths $(0-15) \mathrm{cm}$ have higher values of TPHs than depths $(15-30) \mathrm{cm}$ this could be due to the low soil permeability, type of oil and oil adsorption (NOAA, 1992). Most of the sampled points have TPH concentration higher than the permissible limit for TPHs $(30 \mathrm{mg} / \mathrm{kg})$ (EGASPIN, 2002).

A profile of total polyaromatic hydrocarbon (PAHs) concentration of the sampled area revealed that the concentration of PAH ranged from 0.096 -
$6.890 \mathrm{ppm}$. Sampling points depth (015) $\mathrm{cm}$ have a higher concentration of PAH than depth (15-30) $\mathrm{cm}$ and at 95 $\%$ confidence level; statistically (ANOVA) there is significant difference between them. The concentration of PAH at all sampling points are higher than the permissible limit for PAH $(1 \mathrm{mg} / \mathrm{kg})$ (EGASPIN, 2002) except sampling point $C(15$ 30) $\mathrm{cm}$ which recorded a value of $0.096 \mathrm{ppm}$ as indicated in table 4.Gas chromatogram of PAHs of the sampling points revealed fifteen (15) different PAHs. About $46.7 \%$ are known animal carcinogens, benz (a) anthracene, benzo (b) fluoranthene, benzo (a) fluoranthene, benzo (k) fluoranthene, benzo (a) pyrene, $\operatorname{dibenz}(\mathrm{a}, \mathrm{h})$ anthracene and indeno $(1$, 2, 3 - c d)pyrene (IARC,2000). Anthracene, benzo (g, h, i)perylene, chrysene, fluoranthene, fluorene, phenanthrene and pyrene are not fully classified as to their carcinogenicity (IARC, 2000). The presence of these PAHs possess serious health risk to the people in the vicinity specially the workers. The result from the experiment show that the sample from different location and depth had different population of bacteria. There is an increase in total heterotrophic bacteria and hydrocarbon utilize bacteria over the period of 60 days. The increase in counts may be due to change in the physicochemical property, this is in agreement with works of other researchers (Butier and Mason 1997). The percentage (\%) of hydrocarbon utilizing bacteria to total heterotrophic bacteria at day 0 for various sample point is A $(0-15)$ $34.9 \%$, B (0-15) $11.2 \%$, C (0-15) $7.5 \%$, D (0-15) 9.2\%, E (0-15) 8.3\%, respectively. Because the percentage of HUB count at the site is greater than $1 \%$ which shows the presence of hydrocarbon at the site (Atlas 1992).

This is in agreement with the physicochemical analysis result of the sample as indicated in table 4 . 
The presence of hydrocarbon utilizing bacteria at site impacted with petroleum product suggest the ability to utilize the hydrocarbon as their sole source of carbon and energy for growth (Ekundayo et al, 2012). The hydrocarbon utilizing bacteria isolated belong to the genus Bacillus sp. (38.1\%), Flavobacterium sp. (11.9\%), Pseudomonas sp. (30.9\%), Micrococcus sp. (7.1\%), Arthrobacteria (4.8\%), Acetobacter sp. (2.4\%), Proteus sp. (2.4\%) Stapholoccus sp $(2.4 \%)$. Bacillus sp. and Pseudomonas sp. predominated across the sampling location other researchers also reported the dominance of this organisms at petroleum product contaminated site (Chikere et al., 2009, Chikere and Okpokwasili (2004). The presence of Stapholoccus sp. at the site is interesting, Adams et al., (2014) isolated similar organisms that are capable of degrading PAH. The automechanic workshop contains PAHs, some of which are carcinogenic, therefore, the isolated organisms could be enhance and apply to the site for remediation.

Conclusion: The result of this study reveals eight (8) bacterial genera in the soil sample of the engine oil polluted soil at auto-mechanic workshop. The dominant are Bacillus and Pseudomonas which can be use to bioaugment and remediate auto-mechanic workshops. It is essential that the metagenomic of microorganisms at auto-mechanic workshops be sequence so that their potential to degrade petroleum product contaminants will be exploit fully.

\section{REFERENCES}

Adams, GO; Tawari-Fufeyin, P; Ehinomen, I (2014). Laboratory Scale Bioremediation of Soils from Automobile Mechanic Workshops Using Cow Dung. J. Appl. Environ. Microbiol. 2: 128 -134.

Atlas, RM (1992) Microbial degradation of Petroleum hydrocarbon: An Environmental perspectives, Microbial. Rev. 45: 180 - 201.

Butier, CS; Mason, JR (1997). Structure function analysis of the Bacteria aromatic ring hydroxylating dioxygenase. Adv. Microbiol. Physiol. 38: 47 - 84.

Cheesbrough, M (2000), District Laboratory Practice in tropical countries, Cambridge University Press. United Kingdom 2: 157 - 199.

Chikere, B. O. and Okpokwasili, G. C. (2004). Frequency occurrence of Microorganisms of a petrochemical effluent outfall site. J. Trop. Biosci., 4: 12 -18.

Chikere, B. O. and Okpokwasili, G. C. and Ichiakor O. (2009). Characterization of hydrocarbon utilizing bacterial in Marine sediments. Afr.J. Biotechnol. 8 : 2541 - 2544.

EGASPIN (2002) Environmental Guidelines and Standard for Petroleum industry in Nigeria, Environmental remediation Manual, Lagos.

Ekundayo F. O., Olukunle, OF and Ekundayo, E. A. (2012). Biodegradation of Bonny light Crude oil by locally isolated fungi from oil contaminated soil in Akure, Ondo state. Malaysia Journal of Microbiology, 8: 42 - 46.

Fery, S. D. (2007), Spatial distribution of soil organisms in Eldo. AP, (Ed). Soil Microbiology, Ecology and Biochemistry. Third edition, New York, Elsevier, $283-300$.

Hagwell, IS., Delfino, LM and Roa, JJ (2014), Partitioning of Polycyclic aromatic hydrocarbon from oil into water, Environ SciTechnol 26: 21 30.

IARC Monograph on the Evaluation of the Carcinogenic Risk of chemical to Humans. (2007) Polycyclic Aromatic Hydrocarbon, Part 1, Chemical Environmental Experimental Data. International Agency for Research on Cancer (IARC) Lyon France 32: 1-55.

Jain, PK; Gupta, VK; RK; Lowry, M., Jaroli, DP; Chauhan, UK (2009). Bioremediation of Petroleum oil contaminated soil and water. Research Journal of environmental Toxicology, 5: $1-26$.

Johnson, DL; Ambrose, SH; Bassett, TJ; Bowen, M. L; Crummeg, DE; Isaacson, JS; Johnson, DN; Lamb, P., Saul, M; Winter-Nelson, AE (1997). Meaning of environmental terms, Journal of Environmental Quality 26: 581 - 589.

Michael, MC (2008). Essential Biology. Tonad Publisher Ltd Nigeria.

NOAA (1992) Shoreline Countermeasure Manual, National Oceanic and Atmospheric Administration, Seattle, Washington.

Nwackukwu, M; Feng, H;Alinor, J. (2010), Assessment of heavy metals pollution in soil and their implication with and around mechanic village. $J$. Environ. Sci. Tech, 7: 347 - 358.

Nwoko, C; Okeke P; Agwu, O;Akpan, I (2007), Performance of Phaseolusvillgaris L. in a soil contaminated with spent engine oil. Afr. J. Biotechnol, 6: 19 -22.

Okpokwasili, GC;Okorie, BB (1988).Biodeterioration potentials of Microorganisms isolated from car engine lubricating oil, Trib.Inter.21: 215 - 220.

Onwurah. I; Ogugua, V; Onyike, N;Ochonogor, A; Otitoju, O (2007). Crude oil spills in the environment, effects and some innovative clean-up biotechnologies. Inter. J. Environ. Res. 1:307 320.

U.S Environmental Protection Agency (2002b). Test methods for evaluating solid waste. Third Edition, Report No. SW- 846. U.S Environmental protection Agency, Washington DC. 